\title{
MIKROTIK RB750 ROUTERBOARD SEBAGAI ALTERNATIF SWITCH OPENFLOW SOFTWARE-BASE
}

\author{
Rikie Kartadie \\ Pendidikan Teknologi Informasi \\ STKIP PGRI Tulungagung \\ Email: rikie.kartadie@stkippgritulungagung.ac.id
}

\begin{abstract}
ABSTRAK
Software-Defined Networking (SDN) merupakan cara untuk mengurangi kompleksitas konfigurasi jaringan dan manajemen jaringan. Solusi yang ditawarkan oleh SDN memberikan nuansa baru pada jaringan komputer. Pengimplementasian arsitektur SDN/OpenFlow membutuhkan biaya yang tinggi, sedangkan penggunaan emulator mininet mampu memberikan simulasi yang baik pada skala penelitian, namun dalam kenyataannya implementasinya membutuhkan hardware. Pengimplementasian OpenFlow pada switch telah merambah kebeberapa vendor, diantaranya MikroTik yang telah menambahkan OpenFlow agent pada OS versi 6.17 pada RouterOS nya dan memungkinkannya untuk dapat diimplementasikan pada arsitektur SDN/OpenFlow dengan biaya yang lebih terjangkau. Implementasi OpenFlow agent pada RouterOS MikroTik layak untuk diuji performanya, sebagai alternatif switch OpenFlow software-base. Penelitian ini adalah penelitian awal dari rangkaian penelitian yang akan dilakukan. Langkah-langkah penelitian adalah: (1)Merancang topologi, (2)Simulasi menggunakan emulator mininet sebagai data pembanding (dianggap sebagai representatif dari hardware-base switch), (3)Memodifikasi MikroTik RB750 sebagai prototipe switch OpenFlow software-base, (4) Pengujian prototipe, (5) Analisis hasil dan menarik kesimpulan. Dari hasil uji latency, prototipe memberikan nilai lebih tinggi dibandingkan dengan nilai pembandingnya, nilai throughput TPC dan UDP $1937.5 \mathrm{kbps}$ dan $8.64 \mathrm{kbps}$ dan nilai jitter 0.0093 msec lebih rendah dibandingkan nilai pembandingnya. Prototipe dapat dijadikan alternatif pengganti switch OpenFlow Software-based, walaupun prototipe masih memberikan nilai performa yang rendah.
\end{abstract}

Kata kunci: mininet, mikrotik, software-defined network, openflow.

\begin{abstract}
Software-Defined Networking (SDN) is a way to reduce network configuration complexity and network management. Solution offered by SDN is a fresh new look in a computer network. The implementation of SDN/OpenFlow architecture need a high cost, and the use of mininet emulator is able to give a good simulation at research scale. But, in reality, the implementation of SDN/OpenFlow architecture requires hardware. The implementation of OpenFlow in switch has been expanded to several vendors such as MikroTik. MikroTik added OpenFlow agent on OS version 6.17 on the RouterOS so that the MikroTik can be implemented in SDN/OpenFlow architecture in affordable cost. The performance of the implementation of OpenFlow agent on MikroTik RouterOS is feasible to be tested as an alternative to software-base OpenFlow switch. This study is the beginning of a series of studies that will be done. Research steps are: (1) Designing topology, (2) Simulation using mininet emulator as comparative data (considered as representative of the hardware-base switch), (3) Modify MikroTik RB750 as a prototype OpenFlow software-base switch, (4) Prototype testing, (5) Analysis of the results and draw conclusions. From latency testing results, prototype gives a higher value than the comparison value, the value of TPC and UDP throughput $1937.5 \mathrm{kbps}$ and $1.925 \mathrm{kbps}$ and $0.0093 \mathrm{msec}$ jitter value is lower than comparison value. The prototype can be used as an alternative to software-based OpenFlow switch, though the prototype still gives low performance.
\end{abstract}

Keywords: mininet, mikrotik, software-defined network, openflow.

\section{PENDAHULUAN}

Software Defined Networking (SDN) merupakan cara untuk mengurangi kompleksitas konfigurasi jaringan dan manajemen jaringan. Solusi yang ditawarkan oleh SDN memberikan nuansa baru pada jaringan komputer. Software-Defined Networking (SDN) atau split arsitektur adalah sebuah konsep yang memungkinkan/mengizinkan operator jaringan untuk mengelola router dan switch secara fleksibel menggunakan software yang berjalan di server eksternal [1],[2]. Open Network Foundation sendiri mendefinisikan SDN sebagai sebuah sebuah arsitertur jaringan baru dimana kontrol jaringan dipisahkan dari forwarding dan diprogram secara langsung [3],[4]. 
Pengimplementasian arsitektur SDN/OpenFlow membutuhkan biaya yang tinggi, sedangkan penggunaan emulator mininet mampu memberikan simulasi yang baik pada skala penelitian, namun dalam kenyataannya implementasi membutuhkan hardware [5].

Berdasarkan tesis yang penulis kerjakan dengan judul "Prototipe Infrastruktur Software-Defined Network Dengan Protokol OpenFlow Menggunakan Ubuntu Sebagai Kontroler”, software-based OpenFlow switch memiliki kemampuan yang realtif sama dengan hardware-based OpenFlow switch, yang tentu saja dengan berbagai kekurangannya. Pada tesis tersebut digunakan switch berbasih OpenWRT yang di-implementasi-kan pada switch dari vendor TP-LINK [5].

Hasil uji switch OpenFlow berbasis OpenWRT pada penelitian sebelumnya Performa switch OF softwarebased dapat dikatakan baik dengan hasil gap rata-rata pada setiap pengujian menunjukkan angka yang tidak tinggi. Bahkan pada pengujian jitter dapat dikatakan sama[6].

Pengimplementasian OpenFlow pada switch telah merambah kebeberapa vendor, diantaranya MikroTik. Tanutama dalam bukunya menyatakan bahwa MikroTik adalah sistem operasi independen berbasis Linux khusus untuk komputer yang difungsikan sebagai router. MikroTik didesain untuk mudah digunakan dan sangat baik digunakan untuk keperluan administrasi jaringan komputer seperti merancang dan membangun sebuah sistem jaringan komputer skala kecil hingga yang kompleks. MikroTik mulai didirikan tahun 1995 yang pada awalnya ditujukan untuk perusahaan jasa layanan Internet (Internet Service Provider, ISP) yang melayani pelanggannya menggunakan teknologi nirkabel. Saat ini MikroTik memberikan layanan kepada banyak ISP nirkabel untuk layanan akses Internet di banyak negara di dunia dan juga sangat populer di Indonesia. Mikrotik pada standar perangkat keras berbasiskan Personal Computer (PC) dikenal dengan kestabilan, kualitas kontrol dan fleksibilitas untuk berbagai jenis paket data dan penanganan proses rute (routing). MikroTik yang dibuat sebagai router berbasiskan komputer banyak bermanfaat untuk sebuah ISP yang ingin menjalankan beberapa aplikasi mulai dari hal yang paling ringan hingga tingkat lanjut. Selain routing, MikroTik dapat digunakan sebagai manajemen kapasitas akses (bandwidth, firewall, wireless access point (WiFi), backhaul link, sistem hotspot, Virtual Private Network server) dan masih banyak lainnya[7].

MikroTik telah menambahkan secara optional/pilihan OpenFlow agent pada OS versi 6.17 pada RouterOS nya dan memungkinkannya untuk dapat di-implementasi-kan pada arsitektur SDN/OpenFlow dengan biaya yang lebih terjangkau. Implementasi OpenFlow agent pada RouterOS MikroTik layak untuk diuji performanya, sebagai alternatif switch OpenFlow software-based.

Switch OpenFlow terdiri dari dua jenis, yang pertama adalah hardware-based switch, yang telah dijual secara komersial oleh beberapa vendor [8]. Switch jenis ini telah memodifikasi hardware-nya, menggunakan TCAM- Ternary CAM memungkinkan kondisi pencocokan ketiga " $\mathrm{X}$ " atau "tidak peduli" untuk satu atau lebih bit dalam dataword yang disimpan, sehingga menambah fleksibilitas untuk pencarian. Misalkan, ternary CAM mungkin memiliki kata yang tersimpan dari "10XX0" yang akan cocok dengan empat kata pencarian "10000", "10010", "10100", atau "10110". fleksibilitas pencarian menggunakan sumberdaya yang lebih besar dibandingkan dengan CAM biner sehinga dibutuhkan sel memori internal tambahan yang harus menyandikan tiga kemungkinan bukan dua dari CAM biner [9]. Kondisi tambahan ini biasanya diimplementasikan dengan menambahkan sedikit topeng (bit "peduli" atau "tidak peduli") untuk setiap sel memori, dan menggunakan OS khusus untuk mengimplementasikan Flow-Table dan OpenFlow protokol. Jenis yang kedua adalah software-based switch yang menggunakan sistem UNIX / Linux untuk mengimplementasikan seluruh fungsi OpenFlow switch [10]. Pengaturan flow pada switch OpenFlow dilakukan oleh sebuah kontroler secara terpusat.

Sebuah kontroler pada arsitek SDN bertanggung jawab untuk menambahkan atau menghilangkan flow dari OpenFlow table yang ada didalam perangkat OpenFlow itu sendiri. Ada 2 tipe dari kontroler : Statis, sebuah kontroler statis dapat berupa perangkat yang dapat menambahkan atau menghilangkan flow dari flow table secara statis. Dinamis, sebuah kontroler dinamis memanipulasi isi dari flow sehingga cocok untuk beberapa konfigurasi secara dinamis.

Floodlight yang digunakan pada penelitian ini merupakan kontroler yang digunakan dalam pengembangan proyek SDN (Software Defined Network). Floodlight berlisensi Apache dan berbasis JAVA. Floodlight dirancang untuk bekerja optimal sejalan dengan meningkatnya jumlah switch, router, switch virtual dan jalur akses yang mendukung standar OpenFlow [11].

Penelitian ini adalah penelitian awal dari rangkaian penelitian yang akan dilakukan. Pada penelitian ini dilakukan pengujian latency dan througput pada switch OepnFlow software-based MikroTik.

Latency didefinisikan sebagai penundaan waktu antara saat sesuatu dimulai dan saat ini atau menjadi terdeteksi atau dapat pula diartikan sebagai interval waktu antara stimulasi dan respon, dari sudut pandang yang lebih umum, sebagai waktu tunda antara penyebab dan efek dari beberapa perubahan fisik dalam sistem yang diamati. Dalam hal ini latency dari switch adalah jumlah respon yang dapat diberikan oleh switch dalam tiap detiknya [12].

Throughput secara umum merupakan tingkat capaian atau tingkat di mana sesuatu dapat diproses, untuk jaringan adalah tingkat pengiriman pesan sukses melalui saluran komunikasi, atau dapat pula didefinisikan sebagai jumlah tingkat data yang tersampaikan disemua terminal dalam jaringan . 


\section{METODOLOGI PENELITIAN}

Langkah-langkah pada penelitian ini adalah: (1)Merancang topologi, (2)Simulasi menggunakan emulator mininet sebagai data pembanding (dianggap sebagai representatif dari hardware-base switch), (3)Memodifikasi MikroTik RB750 sebagai prototipe switch OpenFlow software-based, (4) Pengujian prototipe, (5) Analisis hasil dan menarik kesimpulan.

\subsection{Merancang Topologi}

Topologi yang digunakan pada penelitian ini adalah topologi linear yang melibatkan 2 buah switch OpenFlow software-based berbasis MikroTik RB750 yang terhubung dengan sebuah kontroler. Topologi yang digunakan dapat dilihat pada gambar 1 dibawah ini.

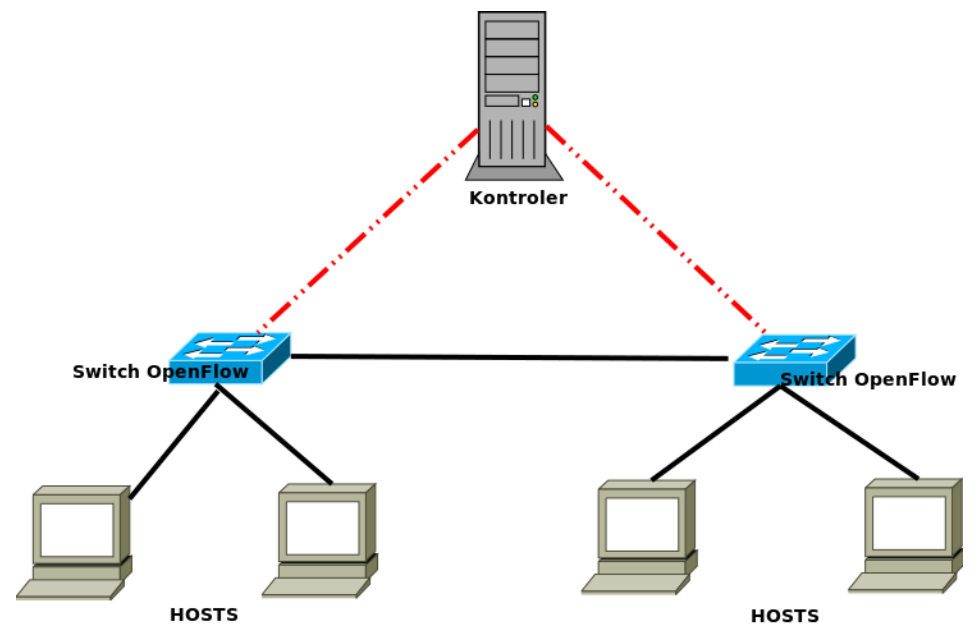

Gambar 1. Topologi Yang Digunakan Dalam Penelitian

Topologi pada gambar 1 digunakan pada simulasi mininet dan digunakan pula pada topologi pada pengujian. Keterangan gambar:

Kontroler Kontroler tersentralisasi yang melakukan kontrol terhadap kedua buah switch.

hosts Host yang terkoneksi langsung ke switch OpenFlow

Switch OpenFlow Switch OpenFlow yang di uji, kedua buah switch tersebut terhubung satu sama lain, dan kedua switch terhubung langsung dengan kontroler.

Koneksi antar perangkat pada jaringan OpenFlow

Koneksi dari kontroler ke switch

\subsection{Simulasi Menggunakan Emulator Mininet}

Topologi yang telah dirancang sebelumnya diujikan pada emulator mininet. Pengujian ini dimaksudkan untuk mendapatkan data pembanding nilai latency dan throughput dengan data pada switch OpenFlow software-based MikroTik yang akan diujikan.

Topologi yang akan diujikan terlihat pada scrip dibawah ini dan disimpan dengan nama file ujibanding.py,

from mininet.topo import Topo

class MyTopo( Topo ):

"Topologi prototipe."

def_init_( self):

"Membuat topologi untuk uji pembanding."

\# Initialize topology

Topo._init__ ( self )

\# Add hosts and switches 


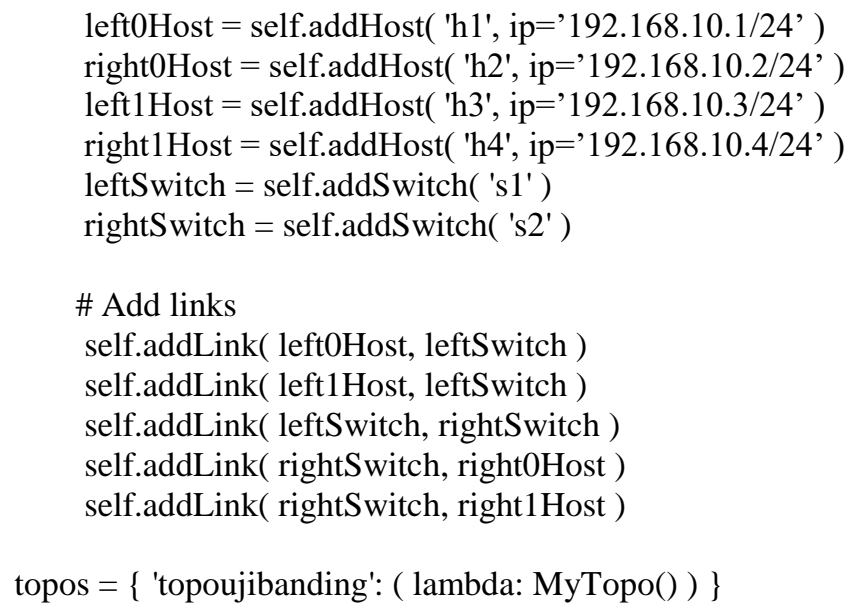

Scrip tersebut dijalankan pada emulator mininet dengan kontroler diletakkan diluar virtualbox yang dijalankan oleh mininet. Scrip dijalankan dengan perintah dibawah ini.

mininet@mininet\#sudo mn --custom ujibanding.py --topo topoujibanding --controller=remote, $\mathrm{ip}=192.168 .1 .76$, port=6633 --mac - -link $\mathrm{tc}, \mathrm{bw}=100$

Mininet dijalankan pada Laptop dengan spesifikasi sebagai berikut:
a) $\mathrm{CPU}$ : Intel ${ }^{\circledR}$ Core $^{\mathrm{TM}} \mathrm{i} 3-4005 \mathrm{U}$ CPU @ $1.70 \mathrm{GHz} \times 4$
b) RAM: SODIMM DDR3 4Gb $1333 \mathrm{MHz}$
c) Hardisk: 259, 1 Gbyte
d) Operation System: Linux UBUNTU 16.04 LTS.

Tentunya kontroler floodlight telah dijalankan terlebih dahulu, dengan perintah

\$ java -jar floodlight.jar

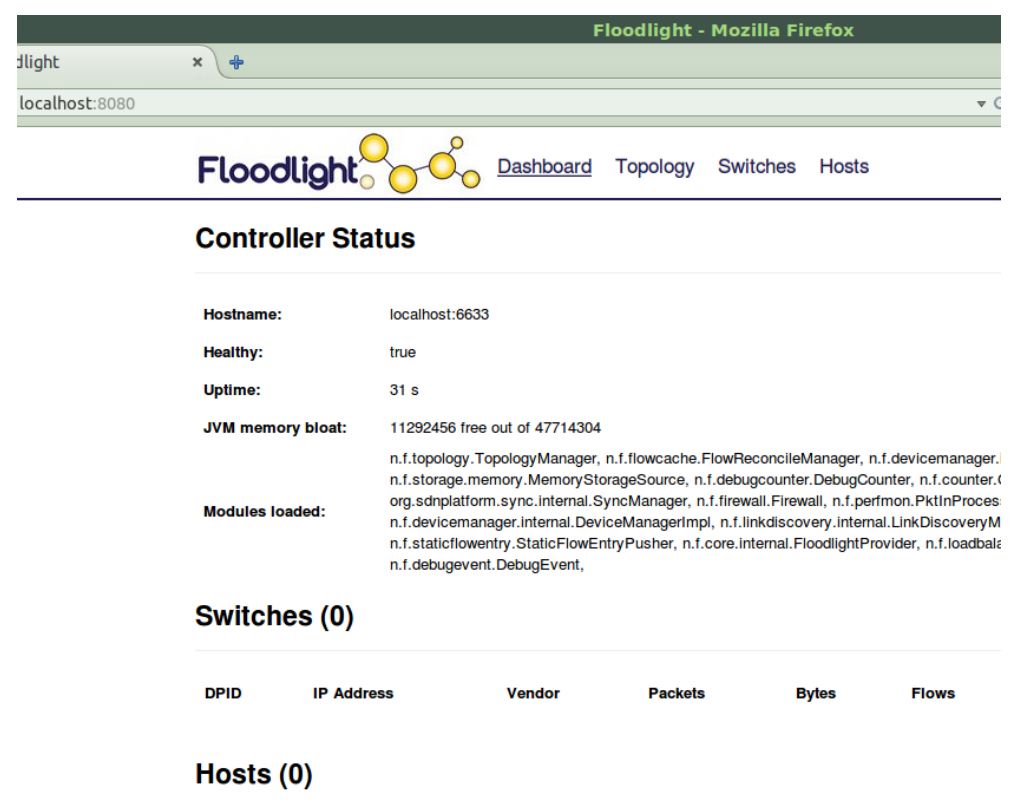

Gambar 2. Kontroler Floodlight

GUI dari floodlight ini dapat diakses pada web browser dengan alamat http://localhost:8080/ui/index.html 


\subsection{Memodifikasi Mikrotik RB750 Sebagai Prototipe}

Prototipe OpenFlow switch software-based dengan menggunakan MikroTik RB750 dapat dilakukan dengan 2 langkah, pertama dengan mengganti OS yang ada dengan OpenWRT dan selanjutnya menambahkan OpenFlow agen kedalamnya, kedua dengan menambahkan paket yang telah disediakan oleh MikroTik, walaupun MikroTik sendiri belum memberikan lisensi terhadap paket ini

Pada penelitian ini, digunakan cara yang kedua untuk menambahkan agent OpenFlow kedalam RouterOS MikroTik RB750. Karna peneliti beranggapan bila dilakukan cara yang pertama, maka tidak ada perbedaan signifikan dengan penelitian sebelumnya.

Langkah pertama yang dilakukan adalah mengupgrade OS MikroTik RB750 dengan versi 6.rc8 (januari 2013). Langkah kedua adalah dengan menambah paket OpenFlow-6.32.2-mipsbe.npk kedalam MikroTik dan mengkatifkan paket tersebut.

\subsection{Pengujian Prototipe}

Pengujian prototipe dilakukan dengan uji latency dan throughput. Pengujian latency yang dilakukan pada prototipe dilakukan pada besar paket ICMP dari 64 byte hingga 8192 byte. Pengujian dilakukan dengan pengulangan sebanyak 15 kali pada setiap paket data ICMP yang dikirimkan.

Pengujian throughput yang dilakukan pada prototipe, dilakukan pada protokol TCP dengan TCP windows size $128 \mathrm{kBps}$ hingga 1024kBps dan UDP Buffer size dan Bandwidth sebesar $128 \mathrm{kBps}$ hingga 1024kBps. Pengujian menggunakan jperf sebagai tool penguji. Pada sisi server, jperf diseting dengan windows sizes mulai dari 128kBps hingga 1024kBps.

$$
\text { iperf -s -P } 0 \text {-i } 1 \text {-p } 5001 \text {-w } 1024 K \text {-f k }
$$

Untuk UDP digunakan seting mulai dari packet size yang sama pula.

$$
\text { iperf -s -u -P } 0 \text {-i } 1 \text {-p } 5001 \text {-w 1024K -f k }
$$

Sedang pada sisi client, jperf diseting dengan konfigurasi

$$
\text { iperf -c 10.0.0.1 -P } 1 \text {-i } 1 \text {-p } 5001 \text {-w } 1024 K \text {-f K -t } 10
$$

Untuk UDP pada sisi client digunakan seting sebagai berikut

$$
\text { iperf -c 10.0.0.1 -u -P } 1 \text {-i } 1 \text {-p } 5001 \text {-w 1024K -f k -b 1024M -t } 10 \text {-T } 1
$$

\section{HASIL DAN PEMBAHASAN}

Dari data yang diperoleh, baik data dari uji pembanding maupun data dari switch OF software-based MikroTik, dilakukan analisis pada nilai latency dan throughput yang dihasilkan. Data yang disajikan adalah nilai rata-rata pengujian.

\subsection{Pengujian Latency}

Pada tabel 1 dan gambar 3 dibawah ini, merupakan data nilai rata-rata latency yang dihasilkan pada setiap pengujian.

Tabel 1. Nilai rata-rata dari setiap pengujian

\begin{tabular}{lllllllll}
\hline & $\begin{array}{l}\mathbf{6 4} \\
\text { byte }\end{array}$ & $\begin{array}{l}\mathbf{1 2 8} \\
\text { byte }\end{array}$ & $\begin{array}{l}\mathbf{2 5 6} \\
\text { byte }\end{array}$ & $\begin{array}{l}\mathbf{5 1 2} \\
\text { byte }\end{array}$ & $\begin{array}{l}\mathbf{1 0 2 4} \\
\text { byte }\end{array}$ & $\begin{array}{l}\mathbf{2 0 4 8} \\
\text { byte }\end{array}$ & $\begin{array}{l}\mathbf{4 0 9 6} \\
\text { byte }\end{array}$ & $\begin{array}{l}\mathbf{8 1 9 2} \\
\text { byte }\end{array}$ \\
\hline Mininet & 2.228 & 3.999 & 4.855 & 5.191 & 4.341 & 4.726 & 4.477 & 9.194 \\
\hline Sw-OF RB & 3.007 & 5.221 & 5.966 & 6.11 & 6.331 & 5.672 & 6.108 & 12.11 \\
& & & & & & & & 1 \\
\hline Catatin
\end{tabular}

Catatan:
Mininet $\quad$ : Nilai latency data pembanding dengan mininet
Sw-OF RB : Nilai latency prototipe
data disajikan dalam msec.

Diperoleh hasil bahwa prototipe mengalami latency yang tinggi diatas nilai latency dari data pembandingnya (mininet). Pada besar paket data ICMP tertentu prototipe mengalami keterlambatan yang lebih tinggi dibanding pembandingnya, seperti dapat dilihat pada gambar 3 dibawah ini. 


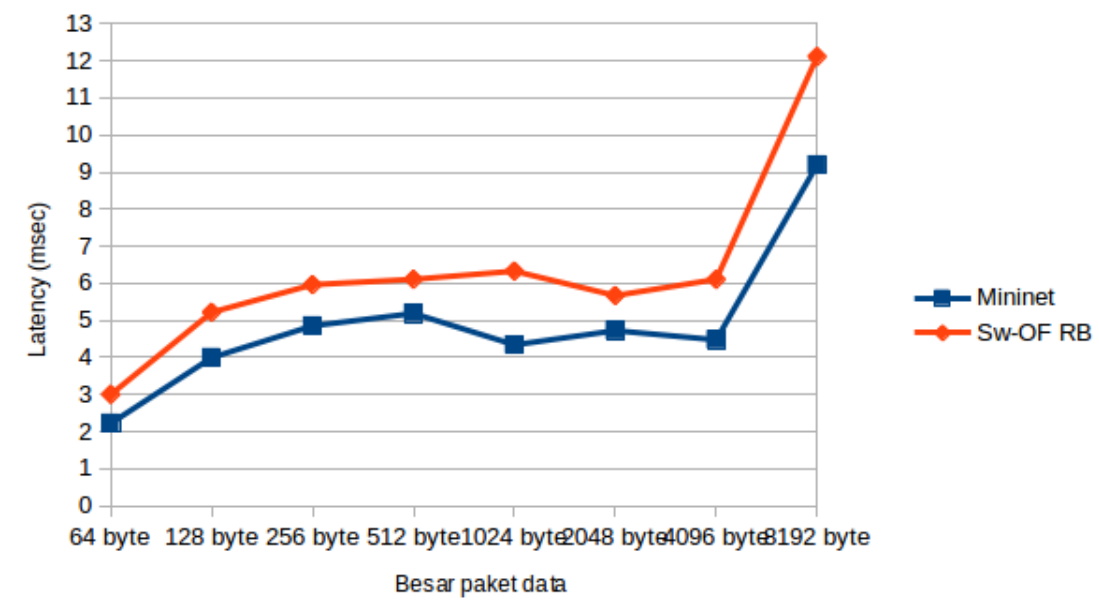

Gambar 3. Grafik Pengujian Latency

\subsection{Pengujian Throughput}

\subsubsection{Protokol TCP}

Pengujian throughput dengan protokol TCP yang diperoleh hasil bandwidth dari mininet dan prototipe seperti pada tabel 2 dan gambar 4 dibawah ini. Data yang digunakan adalah data Rx (Receive).

Tabel 2. Nilai TCP Throughput $\mathbf{R x}$

\begin{tabular}{lllcl}
\hline & 128 kBps & 256 kBps & 512 $\mathbf{~ B p s}$ & $\mathbf{1 0 2 4}$ kBps \\
\hline Mininet & 93216 & 93400 & 93392 & 96771 \\
Sw-OF RB & 91101 & 92762 & 92176 & 92990 \\
GAP rata $^{2}$ & & \multicolumn{2}{c}{-1937.5} & \\
\hline
\end{tabular}

Catatan:

Mininet $\quad$ : Nilai throughput data pembanding dengan mininet

Sw-OF RB : Nilai throughput prototipe

gabrata $^{2} \quad$ : Selisih rata-rata antar nilai throughput prototipe dengan pembanding. data disajikan dalam kbps.

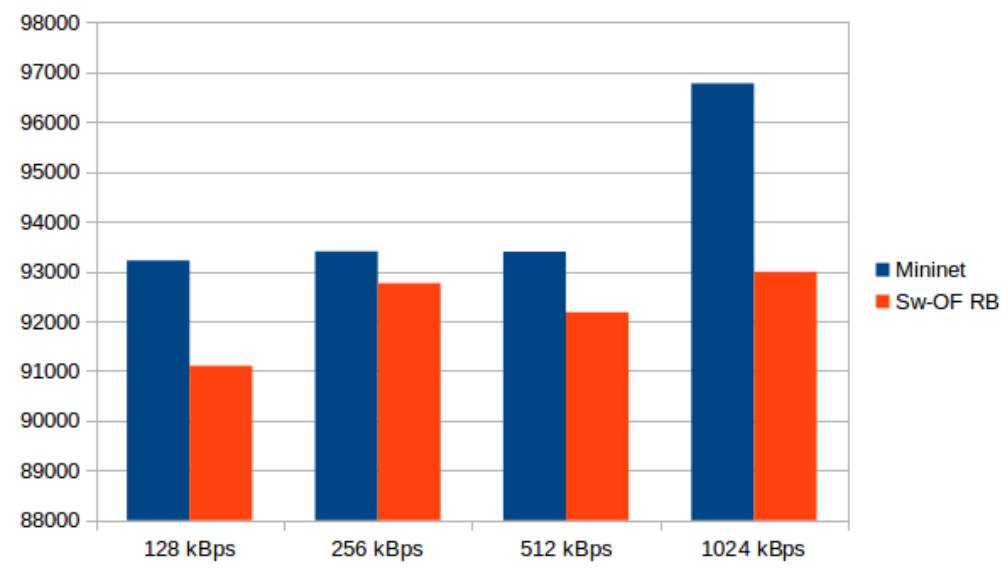

Gambar 4. TCP Throughput Rx

Dari grafik yang terlihat pada gambar 4, throughput protokol TCP yang diperoleh prototipe (switch OF software-based MikroTik) menunjukkan nilai yang kecil dibandingkan dengan pembanding mininet. Kemampuan dari prototipe belum dapat mendekati nilai pembanding pada besar paket $256 \mathrm{kBps}$ dan kemudian tidak mengalami kenaikan yang signifikan. Dapat dimaknai prototipe tidak memiliki kemampuan throughput yang baik, terlebih pada besar data diatas $256 \mathrm{kBps}$. Selisih nilai yang diberikan masih besar yaitu $1937.5 \mathrm{kbps}$ lebih kecil dari pembandingnya. 


\subsubsection{Protokol UDP}

Diperoleh 2 nilai pada pengujian throughput protokol UDP yaitu besar bandwidth dan nilai jitter. Tabel 3 merupakan tabel yang menunjukkan perbedaan bandwidth yang dihasilkan switch pada protokol UDP. Pada gambar 5, dapat dilihat bahwa nilai throughput protokol UDP dari prototipe menunjukkan nilai yang lebih rendah dibandingkan nilai uji pembanding (mininet).

Tabel 3. Nilai UDP Throughput $\mathrm{Rx}$

\begin{tabular}{lllll}
\hline & $\mathbf{1 2 8} \mathbf{k B p s}$ & $\mathbf{2 5 6} \mathbf{k B p s}$ & $\mathbf{5 1 2} \mathbf{k B p s}$ & $\mathbf{1 0 2 4} \mathbf{k B p s}$ \\
\hline Mininet & 15.6 & 31.3 & 62.5 & 125 \\
Sw-OF RB & 12.44 & 26.65 & 58.1 & 102.65 \\
Gap Rata $^{2}$ & & & -8.64 & \\
\hline
\end{tabular}

Catatan:

Mininet $\quad$ : Nilai throughput data pembanding dengan mininet

Sw-OF RB : Nilai throughput switch OpenFlow Software-based MikroTik

gabrata $^{2} \quad$ : Selisih rata-rata antar nilai throughput UDP prototipe dengan pembanding. data disajikan dalam kbps.

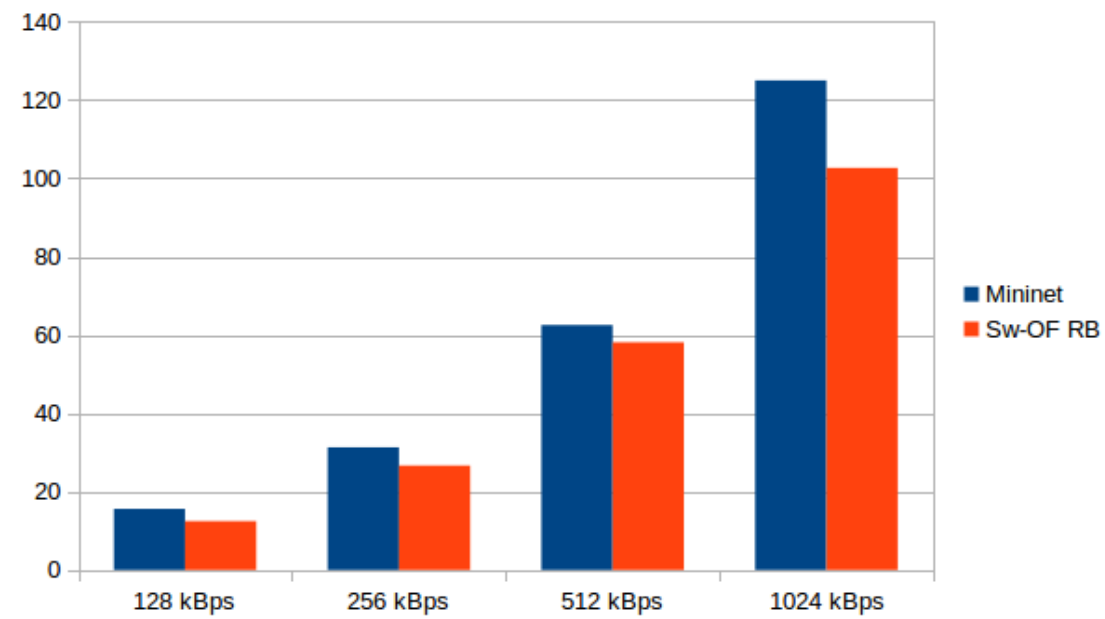

Gambar 5. UDP Throughput Rx

Nilai throughput UDP yang dihasilkan prototipe mempunyai nilai yang rendah dibandingkan dengan mininet sebagai pembanding, namun dengan nilai perbedaan/gap yang signifikan yaitu rata-rata mengalami perbedaan $8.64 \mathrm{kBps}$.

Nilai jitter yang dihasilkan dapat di lihat pada tabel 4 dan grafik 6 .

Tabel 4. Nilai pengujian jitter

\begin{tabular}{lcccr}
\hline & $\mathbf{1 2 8} \boldsymbol{k B p s}$ & $\mathbf{2 5 6} \boldsymbol{k B p s}$ & $\mathbf{5 1 2} \boldsymbol{k B p s}$ & \multicolumn{1}{c}{$\mathbf{1 0 2 4} \boldsymbol{k B p s}$} \\
\hline Mininet & 0.027 & 0.026 & 0.021 & 0.027 \\
\hline Sw-OF RB & 0.034 & 0.032 & 0.034 & 0.0382 \\
\hline Gab rata $^{2}$ & \multicolumn{5}{c}{0.0093} \\
\hline
\end{tabular}

Catatan:

Mininet $\quad$ : Nilai jitter data pembanding dengan mininet

Sw-OF RB : Nilai jitter switch OpenFlow Software-based MikroTik

gabrata $^{2} \quad$ : Selisih rata-rata antar nilai jitter prototipe dengan pembanding.

data disajikan dalam msec. 


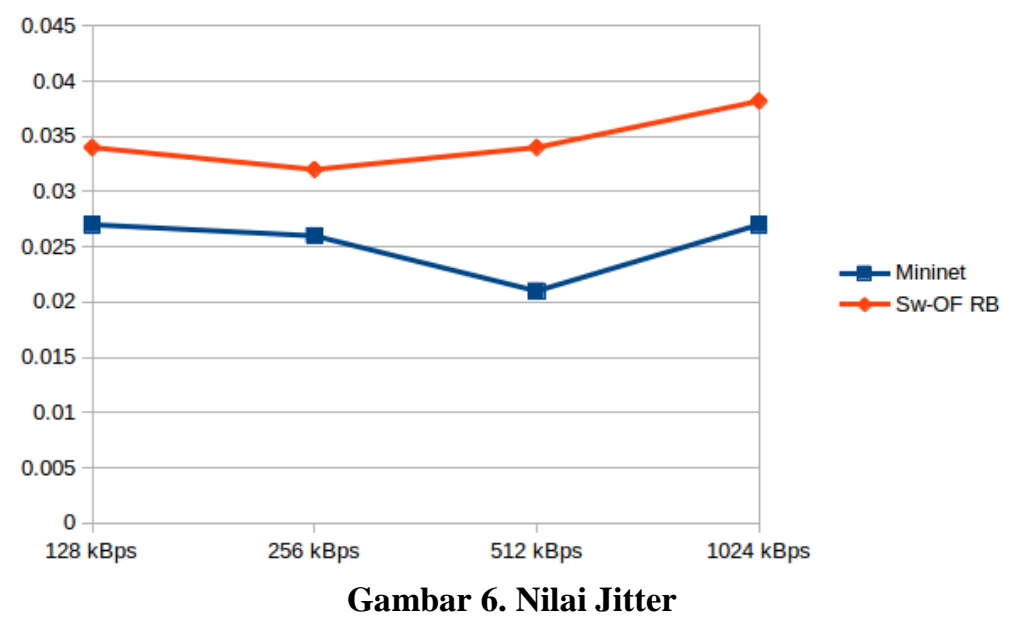

Nilai jitter yang diperoleh menunjukkan bahwa prototipe memberikan nilai yang baik dengan nilai selisih rata-rata sebesar $0.0093 \mathrm{msec}$. Nilai jitter tersebut dapat dinyatakan sama dengan nilai jitter yang diberikan oleh pembandingnya.

\section{KESIMPULAN}

Dari data pengujian yang dilakukan dapat ditarik kesimpulan bahwa:

1) Pada nilai latency, prototipe mendapatkan nilai tinggi dibandingkan dengan pembandingnya, pada semua paket data.

2) Pada pengujian throughput protokol TCP, prototipe memberikan hasil yang rendah dibandingkan dengan pembandingnya, dengan Nilai gap rata-rata prototipe lebih rendah 1937.5 kbps.

3) Pada pengujian throughput protokol UDP, nilai gap throughput bandwidth protokol UDP ratarata prototipe lebih rendah $8.64 \mathrm{kBps}$ dibanding nilai pembanding mininet.

4) Pada pengujian jitter protokol UDP, nilai gap jitter protokol UDP rata-rata prototipe lebih tinggi $0.0093 \mathrm{msec}$ dibanding nilai pembanding mininet. Nilai tersebut dapat dikatakan sama dengan nilai yang dihasilkan oleh pembandingnya.

Dengan melihat hasil yang diperoleh, dapat dikatakan bahwa prototipe dapat dijadikan alternatif pengganti switch OpenFlow Software-based, walaupun prototipe masih memberikan nilai performa yang rendah. Perlu dilakukan pengujian tentang pengolahan TCAM oleh prototipe yang diduga menyebabkan nilai yang diperoleh menjadi rendah dibandingkan nilai pembandingnya.

\section{DAFTAR PUSTAKA}

[1] Mckeown, N. et al,. "OpenFlow: Enabling Innovation in Campus Networks". ACM SIGCOMM Comput. Commun. Rev. vol.38. no.2. pp. 69-74. 2008.

[2] Shirazipour, M. et al,. "Realizing packet-optical integration with SDN and OpenFlow 1.1 extensions”. 2012 IEEE Int. Conf. Commun. pp.6633-6637. 2012.

[3] Paper, W. "Infrastructure SDN with Cariden Technologies". pp.1-14. 2012.

[4] Noname. "Software-Defined Networking: The New Norm for Networks [white paper]". ONF White Pap. pp.1-12. 2012.

[5] Kartadie, R. et al,. "Prototipe Infrastruktur Software-Defined Network Dengan Protokol OpenFlow Menggunakan UBUNTU Sebagai Kontroler”. DASI. 2014.

[6] Kartadie, R. and Satya, B. "Uji Performa Kontroler Floodlight Dan Opendaylight Sebagai Komponen Utama Arsitektur Software-Defined Network”. SEMNASTEKNOMEDIA ONLINE. 2015.

[7] Tanutama, L. (1996). Jaringan Komputer. 1st ed. Yogyakarta: Elex Media Komputindo.

[8] Chung Yik, E. "Implementation of an Open Flow Switch on Netfpga". Universiti Teknologi Malaysia. 2012.

[9] Hucaby, D. (2007). CCNP BSCI Official Exam Certification Guide. 1st ed. Vol.205. no.4594. Indiana: Cisco Press.

[10] Mateo, M, P. “OpenFlow Switching Performance”, Politecnico Di Torino. 2009.

[11] Muntaner, G, R, D, T. "Evaluation of OpenFlow Controllers". p.90. 2012.

[12] Burge, J, E, et al. "What is Rationale and Why Does It Matter?". Ration. Softw. Eng. pp. 3-23. 2008 